76 巻 762 号 $(2010-2)$

\title{
スターリングサイクルを応用した熱スピーカーの原理*
}

\author{
佐藤智明*1
}

\section{Principle of Heat Speaker to which the Stirling Cycle is Applied}

\author{
Tomoaki SATO*2 \\ *2 Department of Mechanical Engineering, Kanagawa Institute of Technology, \\ 1030 Shimo-ogino, Atsugi-shi, Kanagawa, 243-0292 Japan
}

\begin{abstract}
In this paper, as a new application of Stirling cycle, it is proposed to apply the Stirling cycle to heat speaker which amplifies sound vibration by means of the thermal energy. The heat speaker is composed of a pressure vessel whose capacity is variable, a displacer to which a voice coil is attached, a vibration board attached to the pressure vessel and a permanent magnet placed around the vessel. The displacer with voice coil is vibrated by the magnetic force which is generated by electric current of sound signal flowing in the voice coil. The vibrating displacer makes the air come and go between the hot side and the cold side in the pressure vessel. The air temperature goes up and down, and then the pressure follows it. The capacity of the vessel repeats expansion and shrinkage by the pressure change of the air. The moving vessel vibrates the vibration board and it yields the sound.
\end{abstract}

Key Words: Stirling Engine, Sound and Acoustic, Energy Conversion, Speaker

\section{1. はじめに}

スターリングサイクルは，これまで熱エネルギーを 動力に変換する熱機関として，あるいは動力を使って 熱エネルギーを移動させる冷凍装置あるいはヒートポ ンプとして応用されてきた. 本研究では，このような これまでのスターリングサイクルの利用方法とは全く 異なり, 音声信号振動の増幅, 即ちスピーカーに応用 することを提案する. 本報では, 本スピーカーの原理 について解説するとともに，簡単な装置を用いて子備 実験学行い，本スピ一カーの実現可能性について検討 したので報告する.

\section{2. 熱スピーカーの原理}

\section{$2 \cdot 1$ 装置の構成および動作 図 1 に本装置}

の概要寺す。従来のスピーカーはボイスコイル （電磁誘導コイル）と振動板（コーン）が一体と なっており，音声信号電流による電磁誘導で励起 されたボイスコイルの振動が振動板を直接振動さ せ七音波が発生する。本研究の装置は，従来型の スピーカーの振動板部とボイスコイル部を切り離 し，ボイスコイルに円柱状に体積を持たせ，ス夕 一リングエンジンにおけるディスプレーサーとし て動作させる（以下ボイスコイルディスプレーサ

*原稿受付 2009 年 12 月 2 日.

*1 正員, 神奈川工科大学工学部(怎243-0292 厚木市下荻野 1030).

E-mail : satotomo@me.kanagawa-it.ac.jp
一と呼ぶ). ボイスコイルディスプレーサーの作 動する空間は密閉容器となっており，2つのシリ ンダーがハメ合わさった状態で，それでれのシリ ンダーの内壁と外壁が摺動して容積が可変となっ ている(密閉容器の膨張收縮機構はベローズ等を 使ってもよい)。図 1 において，密閉容器は左側 が加熱側，右側が冷却側となっており，ボイスコ イルディスプレーサーが音声振動すると，空気が 容器内を加熱側と椧却側を行き来して加熱および 椧却を繰り返す。これによって，音声信号に同期 した内部温度の上昇および低下が起こり，内部圧 力も上昇扝よび下降を繰り返す。この内部圧力変 化に伴って密閉容器のシリンダーの摺動部が伸縮 する，密閉容器の冷却側の底部（図中右側）には スピーカーの振動板が取り付けてあり，音声信号 によって伸縮するシリンダーの振動によって振動 板が振動し，音波を発生することで本装置のスピ 一カーとしての機能が達成される．また，振動板 が発生する振幅は加熱側と冷却側の温度差, 即ち システムに加えられる熱量の増加とともに増幅さ れる.したがって，本装置はボイスコイルに流す 音声信号電流によって発生した微弱な音声振動を, 熱エネルギーによって，より大きなエネルギーレ ベルの音波に増幅する音声スピーカーとして機能 させることができる。 


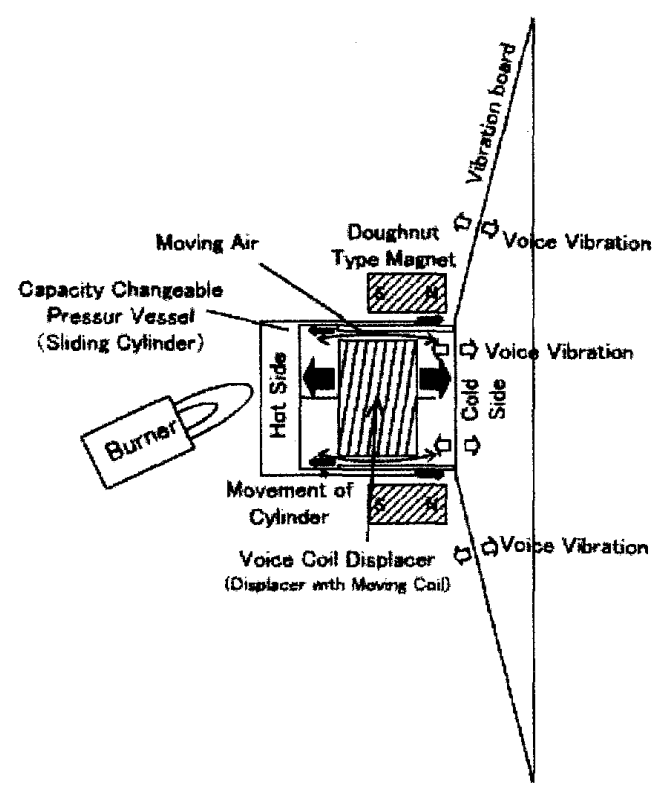

Fig. 1 Principle of Heat Speaker.

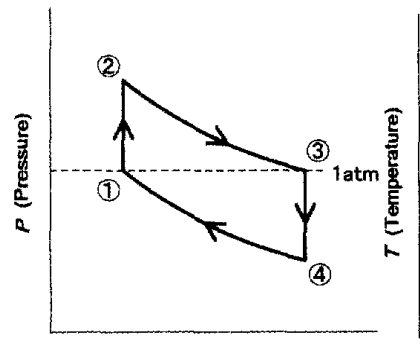

$V$ (Volume)

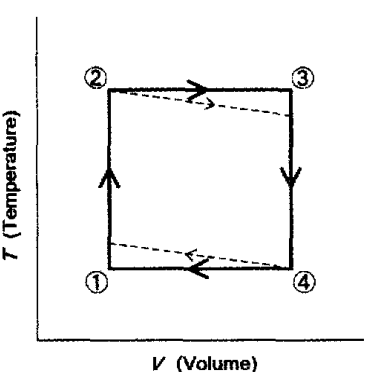

(b) TV (a) PV

Fig. 2 Cycle of the Heat Speaker.

\section{$2 \cdot 2$ 熱スピーカーによる音波発生および増愊の原}

理ここでは, 本システムは理論的にはスターリン グサイクルであるものと仮定して検討を行う。図 2 に サイクル図を示寸.

図 2 中の状態(1)から状態(2)にかけては，図 1 中 の左側 (加熱側) にあったボイスコイルデイスプ レーサーが磁力によって右方向（冷却側）に移動 する。逆に，内部空気は右側 (冷却側) から左側 (加熱側)に移動し，加熱される。これによって， 密閉容器内部空気の平均温度は上昇し, 内部圧力 も上昇する：ここで，音声信号電流の強弱によっ てボイスコイルディスプレーサーの移動量が変化 するため, 加熱量が音声振動の振幅に従って変化 する.

状態(2)から状態(3)ではシリンダ一摺動部が摺動 し容積が膨張する。この時シリンダーに取り付け られたスピーカー振動板は右方向に移動する。振 動板は膨張するシリンダー容器内空気が大気生に なるまで移動する。これが周囲空気を移動させ音
波となる．前述の状態(1)から状態(2)の過程におい て加熱された熱量, 即ち作動流体の上昇温度（上 昇圧力）によってこの移動量（ストローク）も変 化する.また，シリンダ一内空気の膨張時に，一 部の空気が加熱領域から泠却領域に移動するため 内部平均温度は若干低下与る(図 2(b)中の破線部)。

状態(3)から状態(4)では，図 1 中の右側（冷却側） にあったボイスコイルディスプレーサーが磁力に よって左方向 (加熱側) に移動する。逆に，内部 空気は左側 (加熱側) から右側 (冷却側) に移動 し，冷却される。これによって，密閉容器内部空 気の平均温度は低下し, 内部压力も低下する（大 気圧よりも低くなる)。ここで，状態(1)から状態 (2)と同様に, 音声信号電流の強弱によってボイス コイルディスプレーサーの移動量が変化するため, 冷却熱量が音声振動の振幅に従って変化する.

状態(4)から状態(1)では，大気圧に押され，シリ ンダ一摺動部が収縮し，内部空気が圧縮される。 この時シリンダーに取り付けられたスピーカー振 動板は左力向に移動する，振動板は圧縮される内 部空気圧が上昇し大気圧になるまで移動する。こ れが周囲空気を移動させ音波となる，前述の状態 (3)から状態(4)の過程において冷却された熱量, 即 ち作動流体の下降温度（下降圧力）によってこの 移動量（ストローク）も変化する。また，シリン ダ一内空気の圧縮時に，一部の空気が冷却領域か ら加熱領域に移動するため内部平均温度は若干上 昇する（困 2(b)中の破線部）。

以上のように，基本的にはスターリングサイク ルに準じたサイクルを繰り返すことで本スピーカ 一のサイクルが成立する。ここで, 動力機関とし てのスターリングエンジンはパワーピストンのス トロークは固定されているが, 本スピーカーシス テムにおける振動部のストロークは，内部空気の 圧力が大気压になるまでを基準として，入力信号 振動に呼忘して変化するため, 音声信号の複雑な 波形を忠実に再現することができる。

\section{3. 音声信号增幅確認実験}

3-1 実験装置概要および実験方法 本原理 によるスピーカー装置の実現性を確かめるための 実験を行った。図 3 にその概要図を示す。本装置 は，ディスプレーサーをボイスコイルによって振 動させる代わりに，電気モーターによってディス ブレーサーを駆動する. 外部電気モーターによる 回転動力を滑車機構およびクランク機構によって 往復運動に変換し，コネクティングロッドを介し 


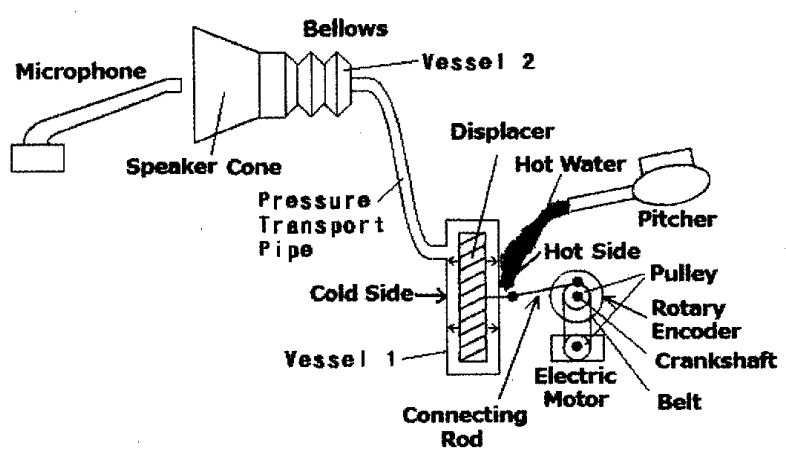

Fig. 3 Experimental Apparatus.

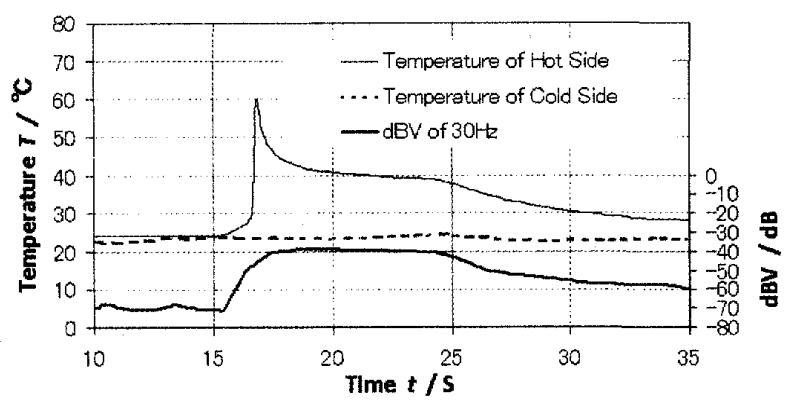

Fig. 4 Experimental Result.

て圧力容器 1 内のディスプレーサーを往復運動さ せる. 圧力容器 1 の片側（図中右側）に熱湯をか け流すことで高熱源側とする.ディスプレーサー の往復運動によって内部作動媒体である空気が加 熱させられたり冷却させられたりすることで内部 の圧力が上下する，この圧力変動を，压力伝達管 を通して, 蛇腹 (ベローズ) から成る内容積可変 な圧力容器 2 に伝える. そして, この圧力変化に よって膨張収縮する蛇腹部に取り付讨られたスピ 一カーコーンを振動させる．スピーカーコーンか ら発せられる音波をマイクロホンによって集音し， コンピューターに取り込んでスペクトル分析する.

$3 \cdot 2$ 実験結果 モーターに電流を流し回転 させる.モーターの回転数はロータリーエンコー ダーによって計測する。モーターの回転を制御し てディスプレーサーの振動が，人間が音として感 じられる周波数の下限範囲である約 $30 \mathrm{~Hz}$ になる ようにする. 加熱面を加熱していない時点では， スペクトル分析結果は, $30 \mathrm{~Hz}$ 付近に顕著な音声振 動（音波）は見られなかった．次に，加熱側面に お湯をかけ流して加熱すると約 $30 \mathrm{~Hz}$ の付近に顕 著な音波が現れた。 その後加熱した面にエアゾー ルスプレーを吹き付けて冷却を行うと温度の低下 に伴って $30 \mathrm{~Hz}$ 付近の音声振動も消滅した.

本実験結果を図 4 に示した。図中にはそれぞれ 加熱面温度, 冷却面温度および $30 \mathrm{~Hz}$ のスペクトル
成分の出力変化を時系列で示した．出力值は音波 を電圧值に変換したマイクロホンの出力電圧につ いて, 基準振幅を $1 \mathrm{~V}$ としたデシベル值で示した. この結果, 加熱面温度の上下動によって $30 \mathrm{~Hz}$ の出 力も上下に呼応していることがわかる。これより， 本システムによって熱エネルギーを使い音声信号 振動を増幅させることが可能であることが証明さ れた。

\section{4. スピーカ一装置としての可能性}

実験の結果, $30 \mathrm{~Hz}$ 付近の音声振動に対して熱工 ネルギーを使った音声信号振動の増幅が実現でき たが，人間が音として感じる周波数は $20 \mathrm{~Hz} \sim$ $20000 \mathrm{~Hz}$ であり，実用的には更に高い周波数につ いても検証していく必要がある。しかし，熱交換 のスピードには限界があることが予想され， $20000 \mathrm{~Hz}$ までの高周波に対して本装置が有効かど うかは不確かである。但し，低周波の音声に特化 したウーハーのようなスピーカーであれば, $100 \mathrm{~Hz}$ 程度の周波数が増幅できれば十分である．音波を 使った熱機関として熱音響スターリングエンジン があるが，既にこれが約 $100 \mathrm{~Hz}$ の音波によってサ イクルを作動させている実績がある(1). 従って， 少なくとも低周波数に特化したウーハースピーカ 一であれば，本方式によるスピーカーが実現可能 であると考える。

また，従来のスピーカーは，コイルに過大な電 流を流すと，ジュール熱によってボイスコイルの 破断が起こるため，その出力に限界があった。し かし，本方式のスピーカーは音声振動の増幅に熱 エネルギーを用いるため，過大な電流を必要とし ない，したがって，これまでの限界を超えた大音 響のスピーカーの開発が可能であると考える.

\section{5. おわりに}

本報では，これまでは熱機関として，あるいは 泠凍装置として応用されてきたスターリングサイ クルの新たな利用方法の一つとして, 音声信号振 動の増幅, 即ちスピーカーに応用することを提案 した. 更に, 簡単な装置を用いて予備実験を行い, 本スピーカーの実現性を確認した。

\section{文献}

(1) Sakamoto S., Tsujimoto T., Hirano H., Fujita T., Watanabe Y., A study on resonant frequency of thermoacoustic cooling system, IEICE technical report. Ultrasonics, Vol.104, No.299 (2004-9), pp. 25-30. 